remote regions of the Union, including the Kola peninsula, the Ural-Kuznetsk Basin, Transbaikalia, the Turukhan region, East Sayan, the Irkutsk region, the Minusinsk region, Buriat Mongolia, and Tanu-Tuva, also the salt and soda lakes of the Kulundin steppe in western Siberia. Aeroplane photography will be used to establish the extent of the Siberian forests. The expedition to Kazakstan is to explore the natural resources of the Karagandin, Koundar, and the Dzeskazgan regions of the Altai and Ridder, and to investigate the possibility of reconstructing the agriculture of north Kazakstan. Seventy-five detachments are starting for Central Asia to explore the natural resources of Tadzhikistan, Turkmenia, Uzbekistan, and Pamir. It has been decided to start to explore this year the natural resources of Khirghizia, which possesses much potential hydraulic power and big deposits of ferrous and non-ferrous metals, and has suitable lands for cattle-breeding. The expedition to the Crimea is to concentrate on the exploration of the salt lakes. The expedition to Transcaucasia will examine the possibilities of utilising hydraulic power in the region, that to the northern Caucasus is to explore the deposits of rare elements such as cadmium and the mineral resources of the main ridge of mountains of the region. In Balkaria an investigation will be made of the soil of the mountain grass-lands. To cover the cost of the expeditions, the Government has allocated six million roubles, and additional sums will be supplied if necessary. These expeditions are to follow up previous exploration work carried out by the Academy of Science in the Yakutsk, Buriato. Mongolsk and Transbaikal regions, which resulted in the discovery of medicinal and other plants suitable for export, and of new areas for rice-growing.

\section{Buildings for Science Departments}

Ar the instigation of the British Science Guild, the Royal Institute of British Architects has undertaken an inquiry into the design of science departments with the view of affording guidance in the matter of accommodation, fittings, finishings, and supply services. An elaborate questionnaire has been drawn up in convenient column form asking for particulars of the sizes of rooms for definite numbers of students, their aspect, wall and floor surfaces, and various laboratory fittings considered desirable. Replies are to be sent to Mr. Alan E. Munby, Science Standing Committee, Royal Institute of British Architects, 9 Conduit Street, London, W.1. Science departments, of course, fall into different categories, and the present inquiry is confined to provisions for higher teaching and research and has been sent to the heads of departments of the universities of the British Empire and certain research institutions. Should an analysis of the returns justify it, the Council of the Royal Institute of British Architects may issue a short report which would put architects and engineers into closer touch with the specific needs of science departments. There can be little doubt that, given adequate response, the questionnaire will give designers of new science departments a valuable body of data on which to base their work.

$$
\text { No. 3264, VoL. 129] }
$$

\section{Mice Plague in Australia}

Prof. W. A. Osborne, University of Melbourne, sends us the following cutting from the Melbourne Argus of March 30, dealing with the present mouse plague in Victoria, Australia : "After all wheat had been trucked from the Lah railway station, near Warracknabeal, a raid was made upon the mice. The site was fenced, and two 40-gallon oil drums were sunk in the ground. The dunnage was then cleared and the mice driven into the drums. On the first night the catch, placed on the weighbridge, weighed one ton, and on two successive nights $8 \mathrm{cwt}$. and $10 \mathrm{cwt}$. were caught, the weight for the three nights being nearly two tons." Prof. Osborne informs us that the greatest visitation of these pests occurred in 1917, when enormous stacks of bagged wheat remained in various railway sidings. The plague was first noticed in February and March of 1917 ; it was at its acme between April and August of the same year. At Lascelles, three tons, approximately 200,000 mice, were caught in one night. Until the end of June 1917, the recorded total caught was 544 tons, at least $32,000,000$ mice.

\section{International Congress of Scientific Management}

THE Fifth International Congress of Scientific Management will be held at the Koloniaal Instituut, Amsterdam, on July 18-23. The subjects to be discussed include costing, markets, technical and mental education of foremen for rationalisation, systems of promotion, rationalisation as a part of education, costs of retail distribution, agricultural labour, and rationalisation in various types of industry. Papers from many countries have been contributed through the national associations or committees and are being published in two volumes in advance of the meeting ; summaries only will be read at the sessions of the Congress. Excursions in Amsterdam, to Eindhoven, the Zuider Zee, and to Rotterdam are being arranged, and continental railways are giving special facilities for those attending the Congress. The general secretary for the Congress is Mr. V. W. van Gogh, Herrengracht 209, Amsterdam-C. English visitors can obtain particulars from the honorary secretary, Institute of Industrial Administration, $44 \mathrm{King}$ William Street, London, E.C.4.

\section{South-Eastern Union of Scientific Societies}

THe thirty-seventh annual Congress of the SouthEastern Union of Scientific Societies will be held in London, at the Civil Service Commission, Burlington Gardens, W.1, on June 1-4, under the presidency of Dr. R. E. Mortimer Wheeler. The presidential address, on "Field Archæology in Great Britain", will be delivered in the evening of the first day of the Congress. The sections, their presidents, and the subjects of the presidential addresses are as follows : archæology, Dr. W. E. St. L. Finny, "Medieval Games and Gaderings" ; botany, Mr. J. Ramsbottom, "Fungi as Scavengers"; geology, Prof. H. L. Hawkins, "The Structure of the South-East of England"; zoology, Mr. Hugh Main, "The Camera as a Naturalist's Recorder" ; regional survey, Mr. G. L. Pepler, 